\title{
CORRIGENDUM
}

\section{ATM-mediated KDM2A phosphorylation is required for the DNA damage repair}

L-L Cao, F Wei, Y Du, B Song, D Wang, C Shen, X Lu, Z Cao, Q Yang, Y Gao, L Wang, Y Zhao, H Wang, Y Yang and W-G Zhu

Oncogene (2016) 35, 402; doi:10.1038/onc.2015.311

Correction to: Oncogene (2016) 35, 301-313; doi: 10.1038/onc. 2015.81; published online 30 March 2015

Since the publication of the above article the authors have requested a change to the author affiliations as per below:

L-L Cao ${ }^{1,4}, \mathrm{~F} \mathrm{Wei}^{1,4}, \mathrm{Y} \mathrm{Du}{ }^{1}$, B Song ${ }^{1}, \mathrm{D} \mathrm{Wang}^{1}{ }^{1}, \mathrm{C}$ Shen ${ }^{1}, \mathrm{X} \mathrm{Lu}{ }^{1}$,

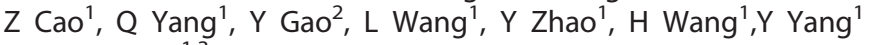
and W-G Zhu ${ }^{1,3}$

${ }^{1}$ Key Laboratory of Carcinogenesis and Translational Research (Ministry of Education), State Key Laboratory of Natural and Biomimetic Drugs, Beijing Key Laboratory of Protein Posttranslational Modifications and Cell Function, Department of
Biochemistry and Molecular Biology, School of Basic Medical Sciences, Peking University Health Science Center, Beijing, China;

${ }^{2}$ Protein Chemistry Facility, School of Biological Sciences, Tsinghua University, Beijing, China and

${ }^{3}$ Peking University-Tsinghua University Joint Center for Life Sciences, Beijing, China. Correspondence: Professor W-G Zhu, Department of Biochemistry and Molecular Biology, Peking University Health Science Center, Xueyuan Road 38\#, Beijing 100191, China.

E-mail: zhuweiguo@bjmu.edu.cn

${ }^{4}$ These authors contributed equally to this work.

The authors wish to apologise for any inconvenience caused. 